\title{
Wohlfahrtiosis in Italy: a case in a puppy and overview of geographical distribution
}

\author{
Teresa Bonacci ${ }^{1}$, Giuseppe Curia ${ }^{2}$, Chiara Scapoli $^{3}$, Marco Pezzi $^{3}$ \\ ${ }^{1}$ University of Calabria, Department of Biology, Ecology and Earth Science, Cosenza, Italy \\ ${ }^{2}$ Azienda Sanitaria Provinciale di Cosenza, Servizio Veterinario, Cosenza, Italy \\ ${ }^{3}$ University of Ferrara, Department of Life Sciences and Biotechnology, Ferrara, Italy
}

Received November 26, 2019

Accepted April 30, 2020

\begin{abstract}
The report describes a case of urogenital myiasis in a puppy, Canis lupus familiaris (Carnivora: Canidae) caused by Wohlfahrtia magnifica (Diptera: Sarcophagidae) in Calabria, southern Italy. This species is an obligatory agent of myiasis in human and other warm-blooded vertebrates. The puppy was healthy and was not living near farm animals, usual hosts of this flesh fly. An overview of cases of human and animal myiasis caused by $W$. magnifica in Italy and of data and specimens documented in entomology museum collections is also reported.
\end{abstract}

Canine, urogenital myiasis, Wohlfahrtia magnifica

Myiasis is an important parasitic disease caused by larvae of Diptera infesting vertebrates actively feeding on host tissues (Zumpt 1965). The term "wohlfahrtiosis" refers to myiasis caused by Wohlfahrtia magnifica (Schiner, 1862) (Insecta: Diptera: Sarcophagidae). Among the types of myiasis, wohlfahrtiosis is especially important not only because it may affect humans, but also because it usually induces serious damage due to the high number of deposited larvae and to their rapid growth. When attacking livestock, the parasite may cause heavy economic damages through loss of production and death (Hall and Farkas 2000).

In Europe wohlfahrtiosis is an infestation reported in humans and domestic animals in several countries, especially in southern and eastern areas. Among domestic animals, those more frequently affected by wohlfahrtiosis are sheep and goats (Hall and Farkas 2000; Sotiraki and Hall 2012; Hall et al. 2016).

This report describes a case of urogenital myiasis in a puppy that occurred in 2017 in Calabria, southern Italy, together with an overview of the documented cases of human and animal myiasis caused by $W$. magnifica reported in Italy, and of the catalogued data and specimens concerning this species in entomology museum collections.

\section{Case description}

The patient was a 4-month male sheepdog puppy, privately owned in San Fili, Cosenza, Italy, living at home and outdoor on hills near a sheep grazing land. The puppy had no documented previous pathology. In August 2017 the puppy exhibited anomalous behavior, showed pain when urinating and loss of appetite. The owners alerted the veterinarian who, during the visit, detected a heavy infestation by dipteran larvae in the preputial region, which appeared seriously damaged (Plate III, Fig. 1A-C). The puppy was anaesthetized with 3\% lidocaine and the veterinarian proceeded to mechanically remove by tweezers 121 larvae of different size (average $10.06 \pm 3.76 \mathrm{~mm}$ ). Most larvae appeared to be in the $3^{\text {rd }}$ instar (Plate III, Fig. 2). The infested region was disinfected by povidone-iodine and hydrogen

Address for correspondence:

Marco Pezzi

Department of Life Sciences and Biotechnology

University of Ferrara

Via L. Borsari 46, 44121, Ferrara, Italy 
peroxide and the injured parts of the preputial mucosa were sutured. An antibiotic drug containing benzathine benzylpenicillin and dihydrostreptomycin sulphate and an antiinflammatory drug containing dexamethasone sodium phosphate were administered intramuscularly for five days. The puppy recovered completely after four weeks. The collected larvae, killed by quick immersion in hot water (about $90^{\circ} \mathrm{C}$ ), were fixed and stored in $80 \%$ ethanol and transported to the Laboratory of Applied and Forensic Entomology, Department of Biology, Ecology and Earth Science of the University of Calabria, Cosenza, Italy. The larval morphology was examined under a Meiji Techno RZ stereomicroscopy (Meiji Techno America, Santa Clara, California, USA) by comparison with specimens from the collection of the Department of Biology, Ecology and Earth Sciences, and by taxonomical keys (Szpila et al. 2014, 2015).

\section{Discussion}

The larvae collected in the preputial region of the puppy were identified as belonging to the species Wohlfahrtia magnifica (Plate III, Fig. 2). The female of this fly is known to deposit larvae not only on host damaged skin or body openings (Patton and Evans 1929) but also on soiled hair and even on hosts with no identifiable predisposing condition (Hall et al. 1995).

In Italy the species has been reported in dogs as an agent of auricular, cutaneous and urogenital myiasis (Table 1). The predisposing conditions for cutaneous myiasis in dogs caused by $W$. magnifica include trauma caused by barbed wire (Bonacci et al. 2017), bites (Carnevali et al. 2019), or lesions caused by surgery (Fois et al. 2012), and skin disease (Bonacci et al. 2013). A case of infestation in the preputial region of a dog without any apparent previous lesion was reported in Sicily (Gaglio et al. 2011). For $W$. magnifica, the preputial region as a site of infestation has been frequently reported in sheep (Farkas et al. 1997; Hall and Farkas 2000; Giangaspero et al. 2011, 2014; Bonacci et al. 2017; Carnevali et al. 2019). In dogs, myiasis caused by $W$. magnifica has been reported not only in Italy but also in other countries such as Greece (Orfanou et al. 2011), Hungary (Farkas et al. 2009), Turkey (Şaki 2004; Ütük 2006; Dik et al. 2012; Kilinç et al. 2013; Gökpinar and Karsli 2018), Iran (Rafinejad et al. 2014; Jamshidi 2016; Moshaverinia and Kazemi Mehrjerdi 2016), Morocco (Farkas et al. 2009), Israel (Schnur et al. 2009), and Russia (Portchinsky 1916).

Infestations by $W$. magnifica without any apparent lesions were reported in Hungary in two dogs: in the first case the dog was affected by otitis externa, and in the second case the infestation was located in the vulva, apparently without any previous lesion (Farkas et al. 2009).

Wohlfahrtiosis in dogs may be epidemiologically relevant because they can act as reservoirs and carrier of this parasite, spreading it among livestock and farm animals (Farkas et al. 2009). This myiasis may develop not only in dogs living near farm animals, but also in healthy domestic individuals living outdoor, as in the reported case. The puppy was apparently healthy without any detectable pathology or lesion that could attract females for larval deposition. However, the puppy's young age could have been a predisposing factor, leading to the inability to perform self-cleaning in the genital region. The lack of self-cleaning may have released odors attracting the $W$. magnifica females (Hall and Farkas 2000).

Wohlfahrtia magnifica, a Palearctic species (Pape 1996), is widely distributed in southern Europe, North Africa, Middle East, and northern Asia up to northwestern China (Povolný and Verves 1997). An overview of the distribution of W. magnifica in Italy was based on reported cases of human and animal myiasis, catalogued data, and specimens in entomology museum collections (Plate IV, Fig. 3, Table 1). This dipteran species is mentioned as 
a component of Italian fauna as early as the $19^{\text {th }}$ century, in the collection of a distinguished Italian entomologist, Professor Mario Bezzi (1868-1927). The collection, located in the Natural History Museum of Milan (Milan, Italy) is mentioned in a later monography on Sarcophagidae (Venturi 1960). The specimens of W. magnifica in the collection were referred to three administrative regions, Abruzzo, Campania, and Lazio: the specimens from Abruzzo bore the date 20 July 1896 and the specimens from Campania and Lazio were reported as collected from cases of human myiasis.

The first documented case of myiasis caused by $W$. magnifica in Italy was reported by the parasitologist Professor Edoardo Perroncito (1847-1936). In correspondence with two other scientists regarding a case of human gastrointestinal myiasis in Ancona (Marche, Italy) in 1899, the parasitologist identified the agent of myiasis as W. magnifica, using its old taxonomic name Sarcophila magnifica (Perroncito 1900). In the early 20 $0^{\text {th }}$ century, three other cases of human myiasis by $S$. magnifica were reported in Italy. The first two cases were auricular myiasis: the first one occurred in 1907 in a baby living in Turin (Piedmont) (Biasioli 1908), and the second one in 1908 in a child living in Taranto (Apulia) (Biasioli 1910). The third case, a cutaneous myiasis, occurred in 1921 in a young man living near Enna (Sicily) (Stancanelli 1922).

Recent inspection of the entomological collection of the Natural History Museum of Venice (Venice, Italy) revealed a specimen of $W$. magnifica reportedly collected in Veneto in August 1938, and three specimens of the same species reportedly collected in FriuliVenezia Giulia in June 1963 (Raffone 2009). No other data were published on this species in Italy until the publication of a research article concerning the distribution of $W$. magnifica in France, Italy, and Spain (Ruíz Martínez and Leclercq 1994). In this article the authors report findings on myiasis in livestock in Abruzzo and Tuscany in 1991, and captured adult flies of the same species in Campania in the same year. However, the geographical coordinates reported as belonging to Abruzzo were actually corresponding to a locality in Lazio (Ruíz Martínez and Leclercq 1994). Several cases of urogenital myiasis in cows were also reported on two farms in central Italy (Ambrosi and Principato 1994).

Reports of myiasis caused by W. magnifica in Italy in animals resumed more recently and have continued to date (Table 1). These cases have been detected in cattle, dogs, sheep, goats, swine and even alpacas, with only single cases detected in a cat, a wild boar, a horse and a rabbit. The reported Italian regions were Apulia, Calabria, Lazio, Molise, Sardinia, Sicily, and Umbria. With regard to humans, two cases were reported in Italy, in August and in September 1997: these are the first reported in Italy after 1921 (Stancanelli 1922). The first case occurred in Sardinia in a farm worker affected by chronic otitis of the middle ear, where the larvae were found (Panu et al. 2000). The second case occurred in Lazio in a boy affected by seborrheic dermatitis causing scalp lesions, who spent the summer in a place frequented by sheep flocks. Many $W$. magnifica larvae were removed from the scalp lesions (Iori et al. 1999). Only three other cases of human myiasis caused by this species have been reported to date in Italy (Lombardo et al. 2002; Boscarelli and Levi Sandri 2016; Cozzani et al. 2017). All were cutaneous: the first case was an infestation detected in a foot of a man who was diagnosed with diabetic vascular necrosis (Lombardo et al. 2002); the second case involved a child and the site of infestation was the periungual area of the right big toe (Boscarelli and Levi Sandri 2016). The third case was a furuncular myiasis detected in the left side of abdomen of a young woman (Cozzani et al. 2017) which was interesting because this type of myiasis is unusual for $W$. magnifica.

The locality where the patients acquired myiasis was not reported but based on the hospital where the condition was treated, the three cases could presumably be allocated to Piedmont, Lazio and Liguria, respectively. All cases of myiasis caused by $W$. magnifica reported in Italy are summarized in Table 1 according to geographical regions, administrative region, host, number, and type of myiasis. 
Table 1. Cases of myiasis by Wohlfahrtia magnifica reported in Italy according to geographical regions, administrative region, host, number and type of myiasis.

\begin{tabular}{|c|c|c|c|c|c|}
\hline Geographical region & Administrative region & Host & N. of cases & Type of myiasis & Reference \\
\hline \multirow{3}{*}{ Northern Italy } & \multirow{2}{*}{ Piedmont } & human & 1 & aur & Biasioli 1908 \\
\hline & & human & 1 & cut & Lombardo et al. 2002 \\
\hline & Liguria & human & 1 & cut & Cozzani et al. 2017 \\
\hline \multirow{18}{*}{ Central Italy } & \multirow{14}{*}{ Lazio } & cattle & 5 & cut; urog & Carnevali et al. 2019 \\
\hline & & $\operatorname{dog}$ & 1 & cut & Giangaspero et al. 2011 \\
\hline & & $\operatorname{dog}$ & 4 & aur; cut & Carnevali et al. 2019 \\
\hline & & horse & 1 & urog & Carnevali et al. 2019 \\
\hline & & goat & 1 & urog & Carnevali et al. 2019 \\
\hline & & human & 1 & NA & Venturi 1960 \\
\hline & & human & 1 & cut & Iori et al. 1999 \\
\hline & & human & 1 & cut & Boscarelli and \\
\hline & & & & & Levi Sandri 2016 \\
\hline & & rabbit & 1 & urog & Carnevali et al. 2019 \\
\hline & & sheep & 83 & cut; opth; urog & Giangaspero et al. 2011 \\
\hline & & sheep & NA & cut; opth; urog & Giangaspero et al. 2018 \\
\hline & & sheep & 30 & aur; cut; urog & Carnevali et al. 2019 \\
\hline & & swine & 2 & urog & Carnevali et al. 2019 \\
\hline & Marche & human & 1 & gastr & Perroncito 1900 \\
\hline & Tuscany & livestock & NA & NA & $\begin{array}{l}\text { Ruíz Martínez and } \\
\text { Leclercq } 1994\end{array}$ \\
\hline & Umbria & alpaca & 5 & aur; cut; urog & Stelletta et al. 2000 \\
\hline & NA & cattle & 53 & urog & $\begin{array}{l}\text { Ambrosi and } \\
\text { Principato } 1994\end{array}$ \\
\hline \multirow{13}{*}{ Southern Italy } & \multirow{3}{*}{ Molise } & sheep & 14 & cut; opth; urog & Giangaspero et al. 2011 \\
\hline & & sheep & 181 & aur; cut; urog & Giangaspero et al. 2014 \\
\hline & & sheep & NA & cut; opth; urog & Giangaspero et al. 2018 \\
\hline & Campania & human & 1 & cut & Venturi 1960 \\
\hline & \multirow{3}{*}{ Apulia } & $\operatorname{dog}$ & 1 & cut & Raele et al. 2017 \\
\hline & & human & 1 & aur & Biasioli 1910 \\
\hline & & sheep & NA & cut; opth; urog & Giangaspero et al. 2018 \\
\hline & \multirow{6}{*}{ Calabria } & $\operatorname{dog}$ & 1 & cut & Bonacci et al. 2013 \\
\hline & & $\operatorname{dog}$ & 1 & cut & $\begin{array}{l}\text { Bonacci and } \\
\text { Brandmayr } 2016\end{array}$ \\
\hline & & $\operatorname{dog}$ & 1 & cut & Bonacci et al. 2017 \\
\hline & & $\operatorname{dog}$ & 1 & urog & present report \\
\hline & & goat & 2 & cut & Bonacci et al. 2017 \\
\hline & & sheep & 6 & cut; urog & Bonacci et al. 2017 \\
\hline \multirow{10}{*}{ Insular Italy } & \multirow{5}{*}{ Sicily } & human & 1 & cut & Stancanelli 1922 \\
\hline & & $\operatorname{dog}$ & 1 & urog & Gaglio et al. 2011 \\
\hline & & goat & 1 & urog & Gaglio et al. 2011 \\
\hline & & sheep & 1 & urog & Gaglio et al. 2011 \\
\hline & & sheep & NA & cut; opth; urog & Giangaspero et al. 2018 \\
\hline & \multirow{5}{*}{ Sardinia } & cat & 1 & oral & Fois et al. 2012 \\
\hline & & $\operatorname{dog}$ & 1 & cut & Fois et al. 2012 \\
\hline & & goat & 1 & cut & Fois et al. 2012 \\
\hline & & human & 1 & aur & Panu et al. 2000 \\
\hline & & wild boar & 1 & cut & Fois et al. 2012 \\
\hline
\end{tabular}

aur - auricular; cut - cutaneous; gastr - gastrointestinal; opth - ophthalmic; urog - urogenital; NA - not available. 


\section{Conclusion}

The reported case of a urogenital myiasis caused by $W$. magnifica in a puppy suggests that dog owners should pay more attention to the health of their animals, especially when they are young and living outdoors, since this species attacks not only wounded or debilitated individuals living near farm animals but also healthy ones with little or no contact with usual hosts. According to present data on distribution of $W$. magnifica, this species is well documented in most Italian regions (Fig. 3), but further investigations should be conducted in all Italian territory, including not only cases of myiasis or field sampling of adult flies, but also a careful survey of historical museum collections.

These data would yield a more complete outline of the Italian distribution of this dangerous parasite, highly relevant in terms of both veterinary and human medicine.

\section{Conflict of interest}

The authors declare no conflict of interest related this work.

\section{Acknowledgements}

We wish to thank Professor Krzysztof Szpila (Department of Ecology and Biogeography, Nicolaus Copernicus University, Torun, Poland) for confirming the identification of Wohlfahrtia magnifica.

This study received no specific grant from any funding agency in the public, commercial or not-for profit sectors.

\section{References}

Ambrosi M, Principato M 1994: Outbreak of vaginomyasis by Wohlfartia magnifica in grazing cattle in Central Italy. Parassitologia 36: 5

Biasioli A 1908: Miasis auricolare. (Auricular myiasis) Arch Ital Otol Rinol Laringol 19: 36-38

Biasioli A 1910: Parassiti rari dell'orecchio. (Unusual ear parasites) Arch Ital Otol Rinol Laringol 21: 478-480

Bonacci T, Greco S, Whitmore D, Curcio U 2013: First data on myiasis caused by Wohlfahrtia magnifica (Schiner, 1862) (Insecta: Diptera: Sarcophagidae) in Calabria, southern Italy. L E B 1: 197-201

Bonacci T, Brandmayr P 2016: Primi dati sui ditteri che causano miasi canine in Calabria. (First data on Diptera causing canine myiasis in Calabria) Proceedings of the $25^{\text {th }}$ National Italian Congress of Entomology. 20-24 June 2016, Padua, Italy

Bonacci T, Curia G, Leoncini R, Whitmore D 2017: Traumatic myiasis in farmed animals caused by Wohlfahrtia magnifica in southern Italy (Diptera: Sarcophagidae). Fragm Entomol 49: 57-60

Boscarelli A, Levi Sandri GB 2016: Periungual myiasis caused by Wohlfahrtia magnifica mimicking an ingrown toenail. Transl Pediatr 5: 95-96

Carnevali F, Franchini D, Otranto D, Giangaspero A, Di Bello A, Ciccarelli S, Szpila K, Valastro C, van der Esch AS 2019: A formulation of neem and hypericum oily extract for the treatment of the wound myiasis by Wohlfahrtia magnifica in domestic animals. Parasitol Res 118: 2361-2367

Cozzani E, Cioni M, Gariazzo L, Javor S, Parodi A 2017: Furuncular myiasis due to Wohlfahrtia magnifica in an Italian patient. Eur J Dermatol 27: 402-403

Dik B, Uslu U, Işik N 2012: Myiasis in animals and human beings in Turkey. Kafkas Univ Vet Fak Derg 18: $37-42$

Farkas R, Hall MJ, Kelemen F 1997: Wound myiasis of sheep in Hungary. Vet Parasitol 69: 133-144

Farkas R, Hall MJ, Bouzagou AK, Lhor Y, Khallaayoune K 2009: Traumatic myiasis in dogs caused by Wohlfahrtia magnifica and its importance in the epidemiology of wohlfahrtiosis of livestock. Med Vet Entomol 23: 80-85

Fois F, Mereu Piras P, Cappai S, Vanin S, Maistrello L, Deiana AM, Cabras PA, Liciardi M 2012: Myiasis by Wohlfahrtia magnifica (Diptera: Sarcophagidae) in different mammals in Sardinia. 27 $7^{\text {th }}$ National Congress of Italian Society of Parasitology, 26-29 June 2012, Alghero, Italy

Gaglio G, Brianti E, Abbene S, Giannetto S. 2011: Genital myiasis by Wohlfahrtia magnifica (Diptera, Sarcophagidae) in Sicily (Italy). Parasitol Res 109: 1471-1474

Giangaspero A, Traversa D, Trentini R, Scala A, Otranto D 2011: Traumatic myiasis by Wohlfahrtia magnifica in Italy. Vet Parasitol 175: 109-112

Giangaspero A, Brianti E, Traversa D, Hall MJR 2014: A retrospective and geographical epidemiological survey of traumatic myiasis in southern Italy. Med Vet Entomol 28: 391-397

Giangaspero A, Gaglio G, Brianti E 2018: Wohlfahrtia magnifica: una minaccia silenziosa. (Wohlfahrtia magnifica: a silent threat) $23^{\text {rd }}$ National Congress of Italian Society of Italian Society of Sheep and Goat Pathology and Production, 12-14 September 2018, Napoli, Italy

Gökpinar S, Karsli B 2018: Traumatic myiasis associated with Wohlfahrtia magnifica and Lucilia sericata larvae in dog. Van Vet J 29: 55-57 
Hall MJR, Farkas R, Kelemen F, Hosier M, El-Khoga JM 1995: Orientation of agents of wound myiasis to hosts and artificial stimuli in Hungary. Med Vet Entomol 9: 77-84

Hall MJR, Farkas R 2000: Traumatic myiasis of humans and animals. In: Papp LB, Darvas B (Eds): Contributions to a manual of Palaearctic Diptera, Volume 1. General and applied dipterology. Science Herald, Budapest, pp. 751-768

Hall MJR, Wall RL, Stevens JR 2016: Traumatic myiasis: a neglected disease in a changing world. Annu Rev Entomol 61: 159-176

Iori A, Zechini B, Cordier L, Luongo E, Pontuale G, Persichino S 1999: A case of myiasis in man due to Wohlfahrtia magnifica (Schiner) recorded near Rome. Parassitologia 41: 583-585

Jamshidi K 2016: Gingival myiasis of dog caused by Wohlfahrtia magnifica, Garmsar, Iran. International Conference on Livestock Health, Welfare and Animal Care, 19-20 April 2016, Istanbul, Turkey

Kılınç ÖO, Oğuz B, Sona A, Biçek K, Özdal N, Değer MS 2013: Bir köpekte Wohlfahrtia magnifica (Schiner, 1862; Diptera: Sarcophagidae) larvalarından ileri gelen travmatik myiasis olgusu. (Traumatic myiasis associated with Wohlfahrtia magnifica (Schiner, 1862; Diptera: Sarcophagidae) larvae in a dog) Animal Health Prod Hyg 2: 209-211

Lombardo S, Cevasco I, Volpe L, Capitolo S, Gerbaudo S 2002: Un caso di miasi in paziente

affetto da arteriopatia diabetica. (A case of myiasis in a patient affected by diabetic arteriopathy) Parassitologia 19: 105-109

Moshaverinia A, Kazemi Mehrjerdi H 2016: Canine myiasis and its causal agents in Northeastern Iran. Iran J Parasitol 11: 91-97

Orfanou DC, Papadopoulos E, Cripps PJ, Athanasiou LV, Fthenakis GC 2011: Myiasis in a dog shelter in Greece: epidemiological and clinical features and therapeutic considerations. Vet Parasitol 181: 374-378

Panu F, Cabras G, Contini C, Onnis D 2000: Human auricolar myiasis caused by Wohlfartia magnifica (Schiner) (Diptera: Sarcophagidae): first case found in Sardinia. J Laryngol Otol 114: 450-452

Pape T 1996: Catalogue of the Sarcophagidae of the World (Insecta: Diptera). Mem Entomol Int 8: 1-558.

Patton WS, Evans AM 1929: Insects, ticks, mites and venomous animals of medical and veterinary importance. Part I. Medical Public Health. Liverpool School of Tropical Medicine, Liverpool, 786 p.

Perroncito E 1900: Le larve della "Sarcophila magnifica" (Schiner) nell'intestino dell'uomo. (The larvae of "Sarcophila magnifica" (Schiner) in human intestine) Giornale della Reale Accademia di medicina di Torino 6: 522-525

Portchinsky IA 1916: Wohlfahrtia magnifica, Schin., and allied Russian species. The biology of this fly and its importance to man and domestic animals. Memoirs of the Bureau of Entomology of the Scientific Committee of the Ministry of Agriculture, Saint Petersburg 11: 1-108

Povolný D, Verves YG 1997: The flesh-flies of Central Europe (Insecta, Diptera, Sarcophagidae). Spixiana Supplement 24: 1-260

Raele DA, Galante D, Pugliese N, Cafiero MA 2017: Traumatic cutaneous myiasis by Wohlfahrtia magnifica in a stray dog in Italy. J Small Anim Pract 58: 539

Raffone G 2009: Nuovi dati sulla distribuzione in Italia di alcuni Sarcophagidae (Insecta, Diptera, Brachycera). (New data on the distribution in Italy of some Sarcophagidae (Insecta, Diptera, Brachycera) Boll Mus Civ St nat Venezia 60: 103-111

Rafinejad J, Akbarzadeh K, Rassi Y, Nozari J, Sedaghat MM, Hosseini M, Alipour H, Ranjbar A, Zeinali D 2014 : Traumatic myiasis agents in Iran with introducing of new dominant species, Wohlfahrtia magnifica (Diptera: Sarcophagidae). Asian Pac J Trop Biomed 4: 451-455

Ruíz Martínez I, Leclercq M 1994: Data on the distribution of screwworm fly Wohlfahrtia magnifica (Schiner) in Southwestern Europe (Diptera: Sarcophagidae). Notes fauniques de Gembloux 28: 53-60

Şaki CE 2004: Elazığ'da köpeklerde tespit edilen travmatik myiasisler. (Traumatic myiasis of dogs in Elazı ̆̆, Turkey) F Ü Sağlık Bil Vet Derg 18: 29-33

Schnur HJ, Zivotofsk D, Wilamowski A 2009: Myiasis in domestic animals in Israel. Vet Parasitol 12: $352-355$

Sotiraki S, Hall MJ 2012: A review of comparative aspects of myiasis in goats and sheep in Europe. Small Ruminant Res 103: 75-83

Stancanelli P 1922: Myiasis muscosa (da Sarcophaga magnifica Schiner) su tigna favosa. (Myiasis by Sarcophaga magnifica Schiner on flavus) Policlin Sez Prat 29: 1357-1359

Stelletta C, Principato M, Morgante M, Testoni S, Ranucci S 2000: Dermomiasi da Wohlfartia magnifica (Diptera: Sarcophagidae) in Alpaca (Lama pacos) allevati nel centro Italia. (Dermomyiasis by Wohlfartia magnifica (Diptera: Sarcophagidae) in alpacas (Lama pacos) bred in central Italy) $8^{\text {th }}$ International Congress of Mediterranean Federation for Health and Production of Ruminants, 27-30 April 2000, Giardini Naxos, Italy

Szpila K, Hall MJ, Wardhana AH, Pape T 2014: Morphology of the first instar larva of obligatory traumatic myiasis agents (Diptera: Calliphoridae, Sarcophagidae). Parasitol Res 113: 1629-1640

Szpila K, Richet R, Pape T 2015: Third instar larvae of flesh flies (Diptera: Sarcophagidae) of forensic importance - critical review of characters and key for European species. Parasitol Res 114: 2279-2289

Ütük AE 2006: Bir köpekte travmatik miyazis olgusu. (Traumatic myiasis in a dog) F Ü Sağlık Bil Vet Derg 20: 97-99 
Venturi F 1960: Sistematica e geonemia dei sarcofagidi (excl. Sarcophaga Meig. s. 1.) italiani (Diptera). (Systematics and biogeography of Italian sarcophagids (excl. Sarcophaga Meig. s. 1.) (Diptera)) Frustola Entomologica 2: 1-124

Zumpt F 1965: Myiasis in man and animals in the old world. Butterworth \& Co., London, 267 p. 
Plate III

Bonacci T. et al.: Wohlfahrtiosis ... pp. 171-177

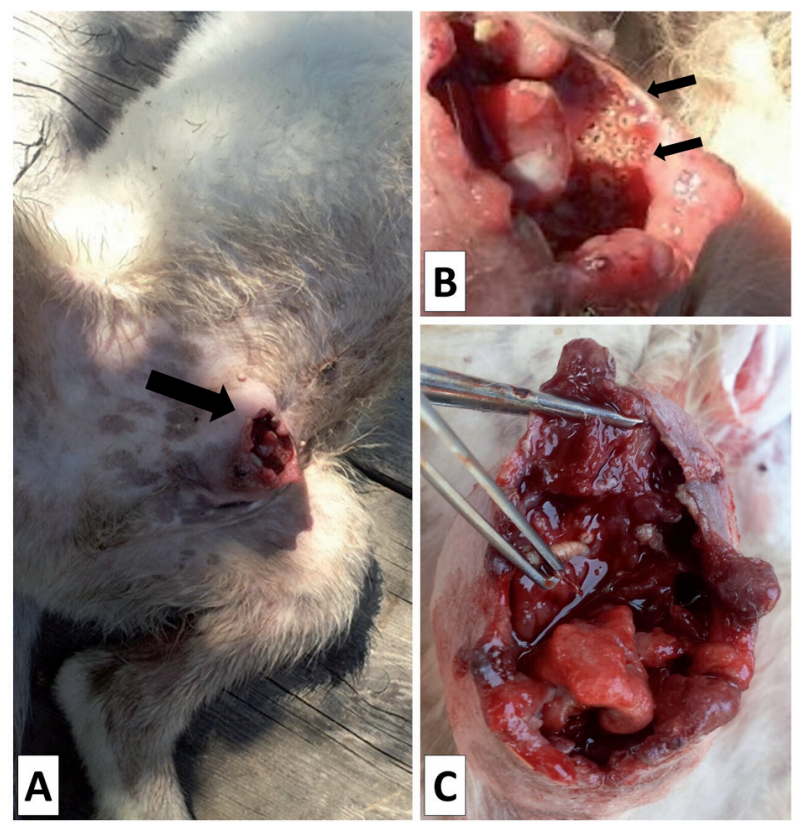

Fig. 1. Clinical aspects of urogenital myiasis in a sheepdog puppy infested by Wohlfahrtia magnifica (Diptera: Sarcophagidae). (A) Lower abdomen showing the preputial region (arrow) affected by the parasite. (B) Detail showing the larvae of $W$. magnifica (arrows). (C) Extensive damage of the preputial region caused by the larvae

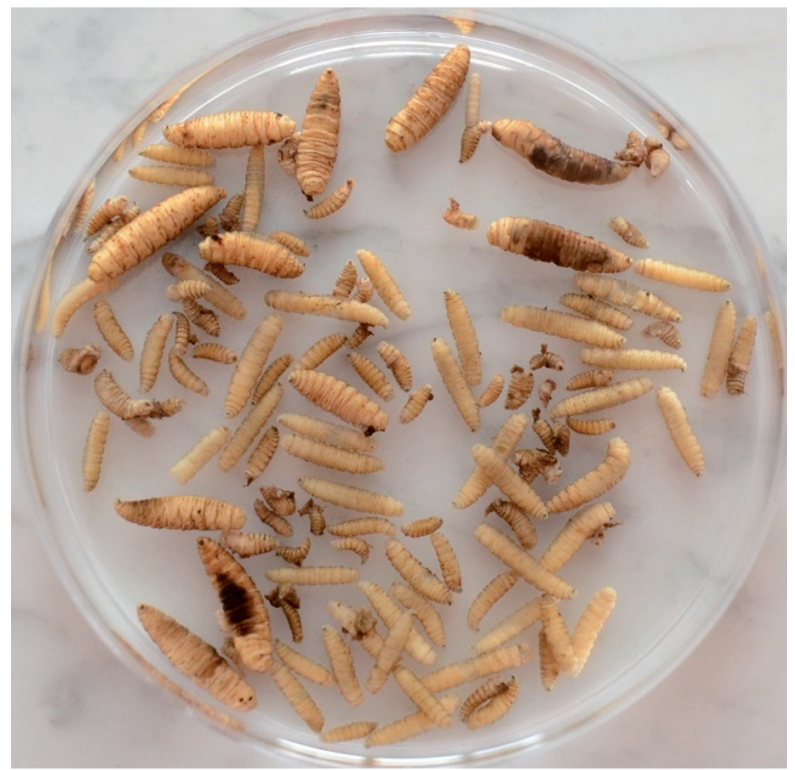

Fig. 2. Larvae of $W$. magnifica at different instars removed from the preputial region 


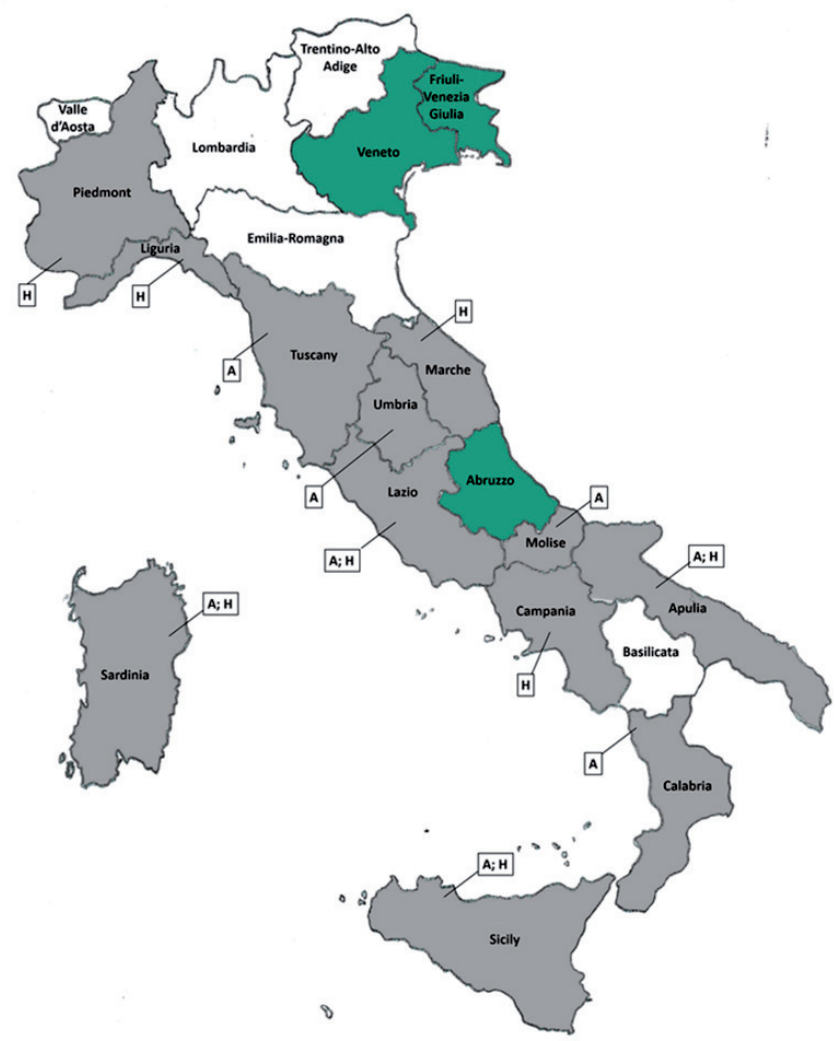

Fig. 3. Map of Italian administrative regions showing where human and animal cases of myiasis caused by W. magnifica were reported (grey) and where only individuals of this species were collected (green). Abbreviations: $\mathrm{A}$, animal myiasis; $\mathrm{H}$, human myiasis 